\title{
Performance Test of Solar-Powered Ice Maker: Case Study in South Lampung
}

\author{
Putri Wullandari ${ }^{1}$, Arif Rahman Hakim ${ }^{1}$, and Widiarto Sarwono ${ }^{1}$ \\ ${ }^{1}$ Indonesian Research Institute for Fisheries Post-harvest Mechanization
}

\begin{abstract}
The performance test of solar powered ice maker is being held at the fish auction spot of Kramat, South Lampung for 6 hours. The spesification of ice maker are: having the production capacity of $105-120 \mathrm{~kg} /$ day, producing flakes ice with $2 \times 3 \times 3 \mathrm{~mm}$ dimension. The spesification of solar panel are: having maximum power of $200 \mathrm{~W}, 1,32 \mathrm{~m}$ length, $0,992 \mathrm{~m}$ width, and $1,3094 \mathrm{~m}^{2}$ area. In this test, we used 9 solar panel with the total area of $11,7846 \mathrm{~m}^{2}$. During the performance test, the intensity of sunlight, battery voltage, battery capacity, power input from solar panel, battery discharge current, maximum power consumption of ice maker, and total ice production are being measured. The sunlight-intensity value (lumen $/ \mathrm{m}^{2}$ ) and the power input of the solar panel (watts) was plotted into a graph. Once the graph is created then add the trendline and create the equation. In a sunny-yet-cloudy weather conditions (at $24-33^{\circ} \mathrm{C}$ temperature and $65-95 \%$ humidity) in South Lampung, the relationship between the sunlight intensity with the power input of the solar panel is linear with the equation $y=0,008 x+143.6$. Where the maximum intensity of sunlight is $121600 \mathrm{~lm}$ $/ \mathrm{m}^{2}$ with the maximum power input of the solar panel $(9 \times 200 \mathrm{Wp})$ is $1253 \mathrm{~W}$. Total ice production for 6 hours is $28.42 \mathrm{~kg}$ or $4.74 \mathrm{~kg}$ per hour. This production resulted from a $760 \mathrm{~W}$ ice maker with a starting current of $4.6 \mathrm{~A}$ with a total power of $3.94 \mathrm{kWh}$.
\end{abstract}

\section{Introduction}

In recent years, increasing attention is being given to the use of waste heat and solar energy in energising refrigerating systems. Solar powered refrigeration and air conditioning have been very attractive during the last twenty years, since the availability of sunshine and the need for refrigeration both reach maximum levels in the same season. One of the most effective forms of solar refrigeration is in the production of ice, as ice can accumulate much latent heat, thus the size of the ice maker can be made small.

The cooling system has become an important part of human life, most of the refrigeration system is sourced from electrical energy [1]. However, electrical energy has not reached all areas of human residence, especially for people living in rural areas.

One of the alternatives to substitute electrical energy is the use of solar energy. The use of solar energy is one of the important contributions to reduce fossil fuel consumption and harmful emissions for the environment. Meanwhile, a solar-powered cooler for food, beverages and seafood or air-conditioning is an interesting solar energy application because both the supply of insulation and the need for cooling reach maximum levels in the same period [2].

The sun supplies energy to the earth in the form of radiation. Every year there is $3.9 \times 10^{24}$ Joule or equal to $1.08 \times 10^{18} \mathrm{kWh}$ solar energy reaches the earth's surface. The intensity of solar radiation outside the atmosphere depends on the distance between the earth and the sun.

\footnotetext{
*Corresponding author: utides@gmail.com
}

Throughout the year, the distance between the earth and the sun varies between $1.47 \times 10^{8} \mathrm{~km}$ to $1.52 \times 10^{8} \mathrm{~km}$. As a result, irradiance $\left(\mathrm{E}_{0}\right)$ fluctuates between $1,325 \mathrm{~W} . \mathrm{m}^{2}$ to $1,412 \mathrm{~W} / \mathrm{m}^{2}$. The average value of irradiance is called solar constant, $\mathrm{E}_{0}=1,367 \mathrm{~W} / \mathrm{m}^{2}[3]$.

The biggest difference between ice making and air conditioning is that the evaporation temperature for ice making is about $-5^{2} \mathrm{C}$, which is lower than that for air conditioning, leading to low efficiency and high pressure ratio for compressor used for ice maker [2].

\section{Methodology}

\subsection{Materials}

Materials used in the process of machine design are stainless steel or plate, capillary pipe, compressor, condenser, condenser fan, accumulator, expansion / expansion valve, evaporator, and other mechanical / electrical materials such as cable, insulation, switch and fuse, R404a refrigerant, solar panel, battery, solar charge controller, cable, inverter, water pump, neodymium magnet, motor-generator type brush.

\subsection{Equipment}

Equipment used in the design process of machine is bending tools, welders, welding tools, grinding wheels, sealed cutting tools, saws, hand drills, miser, and other workshop equipment. The equipment used for performance testing are luxmeter, ampere pliers, laptop, 
stopwatch, mercury thermometer, digital scales, , electric current meter, and electric voltage meter.

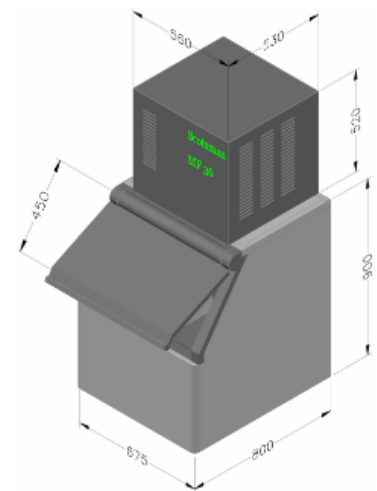

Figure 1. Flakes ice maker machine.

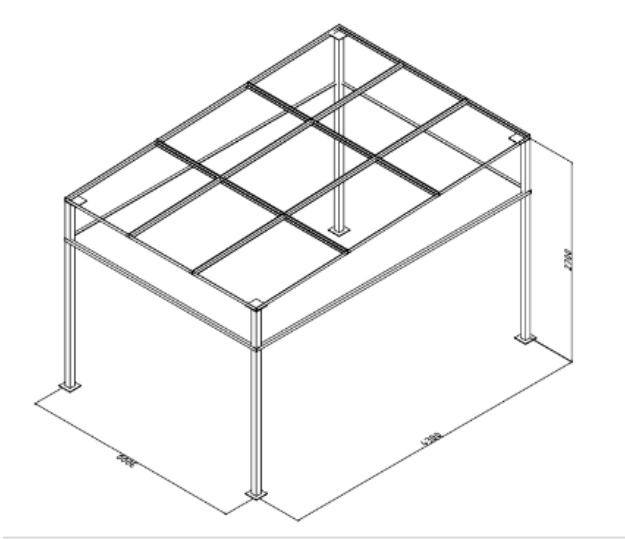

Figure 2. Solar panel's frame.

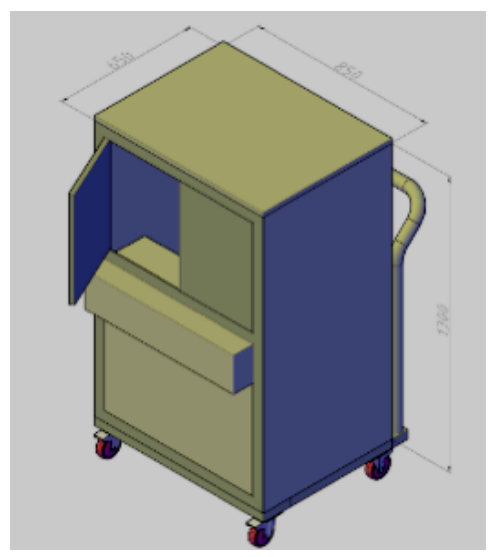

Figure 3. Box for storing inverters and batteries.

The specifications of solar panels that being used in this research are presented in Table 1.
Table 1. Solar panel's spesification.

\begin{tabular}{|l|l|l|}
\hline Merk & $:$ & ICA solar \\
\hline Solar Panel Type & $:$ & Polycrystalline \\
\hline Maximum Power (Pmax) & $:$ & $200 \mathrm{~W}$ \\
\hline $\begin{array}{l}\text { Maximum Power Voltage } \\
\text { (Vmp) }\end{array}$ & $:$ & $35.8 \mathrm{~V}$ \\
\hline $\begin{array}{l}\text { Maximum Power Current } \\
\text { (Imp) }\end{array}$ & $:$ & $5.59 \mathrm{~A}$ \\
\hline Open Circuit Voltage (Voc) & $:$ & $44.85 \mathrm{~V}$ \\
\hline Short Circuit Current (Isc) & $:$ & $5.92 \mathrm{~A}$ \\
\hline $\begin{array}{l}\text { Nominal Operating Cell } \\
\text { Temp. (NOCT) }\end{array}$ & $:$ & $45^{\circ} \mathrm{C} \pm 2^{\circ} \mathrm{C}$ \\
\hline Maximum System Voltage & $:$ & $1000 \mathrm{VDC}$ \\
\hline Maximum Series Fuse & $:$ & $10 \mathrm{~A}$ \\
\hline $\begin{array}{l}\text { For field connections, use } \\
\text { copper }\end{array}$ & minimum No.12AWG \\
\hline Wires insulated for a minimum $90^{\circ} \mathrm{C}$ \\
\hline Weight & $:$ & $15.3 \mathrm{~kg}$ \\
\hline $\begin{array}{l}\text { Dimension } \\
\text { Standard Test Condition }\end{array}$ & $: \begin{array}{l}1320 \times 992 \times 40 \\
\text { mm }\end{array}$ \\
\cline { 2 - 3 } & $:$ & Air Mass $=1.5$ \\
\cline { 2 - 3 } & $:$ & $\begin{array}{l}\text { Irradiance }=1000 \\
\mathrm{~W} / \mathrm{m}^{2}\end{array}$ \\
\hline
\end{tabular}

\subsection{Methods}

The method used in this research is presented in Figure 3.

This performance test of solar-powered ice maker is part of machine performance test by users. The details are : first we assembly the flakes ice maker machine and the solar panel, and then we operate the flakes ice maker machine and the solar panel for 6 hours while measuring the intensity of sunlight, battery voltage, battery capacity, power input from solar panel, battery discharge current, maximum power consumption of ice maker, and total ice production. After that, we process the data using Microsoft Excel. The sunlight intensity and the power input from solar panel are being plotted in the graph to determine the relationship that will be shown in the equation. 


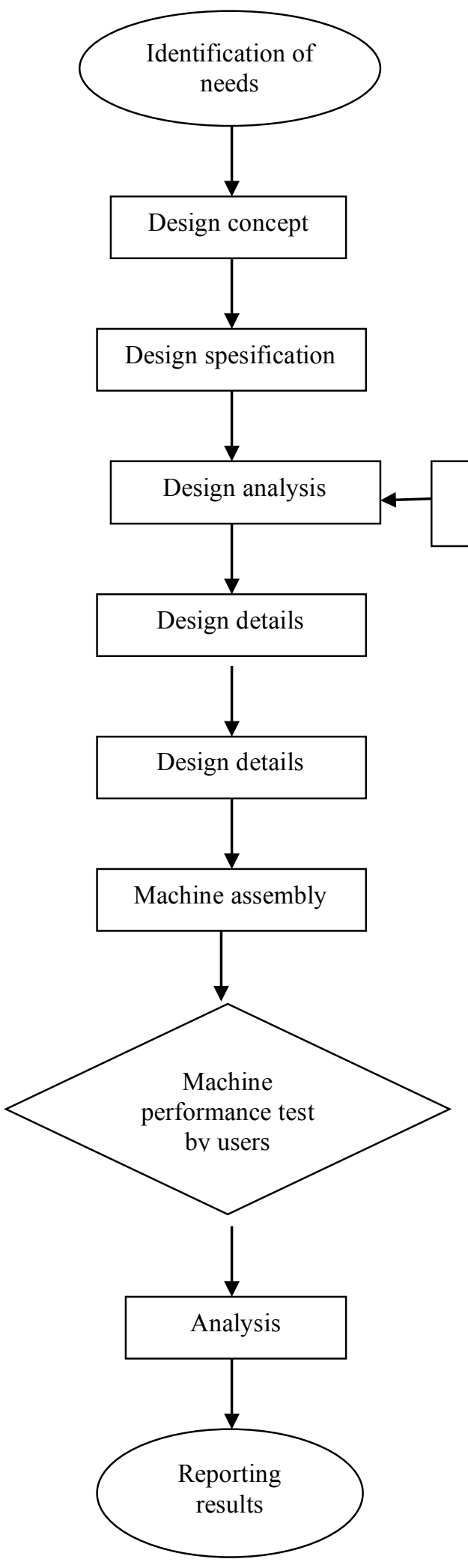

Figure 3. Flow diagram of the research.

\section{Results and discussion}

Tempat Pelelangan Ikan Kramat is located in Dusun Kramat, Sumur Village, Ketapang Subdistrict, South Lampung Regency. This is a landing place for local fisherman. The location of TPI Kramat is very appropriate to be a field-location test for ice maker because the supply of freshwater and electricity in this area is sufficient.

The needs of ice as a cooler in this location is not too big that only seven blocks of ice for normal conditions and at the time of fish season the required amount reaches twice as much.

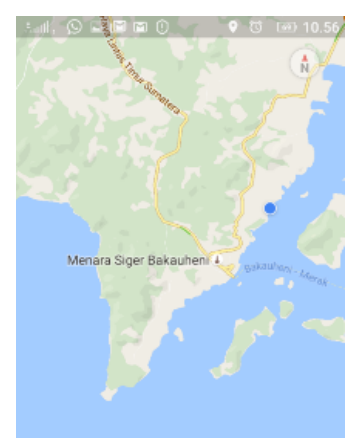

Figure 4. TPI Kramat's location.

The stages of assembly activities of the ice maker machine are :

a. Assembling 9 solar panels to get the power of $2000 \mathrm{~W}$.

b. Preparing the arrangement of ice maker machine and hybrid inverter / charger

c. Preparing fresh water availability for ice machine water supply. The fresh water is obtained from drilled wells that is being patched in reservoirs.

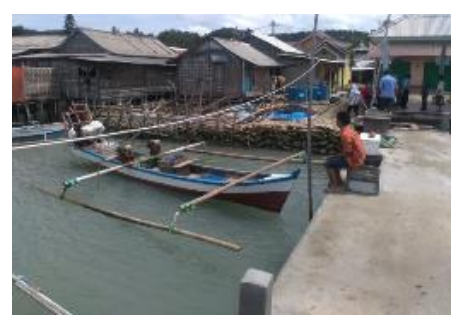

Figure 5. TPI Kramat's condition.

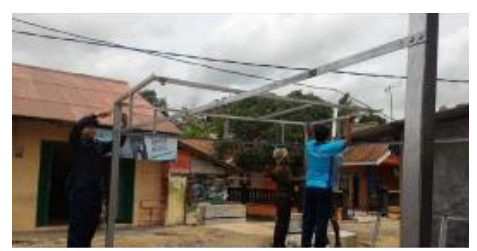

Figure 6. Assembling of solar panel's frame. 
Solar powered-ice maker performance test is done by measuring the intensity of sunlight (lumen) per time unit, recording the power input data and voltage from solar panel, voltage and battery capacity, charging current of battery, discharge current of battery, and weather conditions at the time of testing.

Display of power input and voltage data from solar panel, voltage and battery capacity, charging current of battery, discharging current from battery is shown in Figure 7.

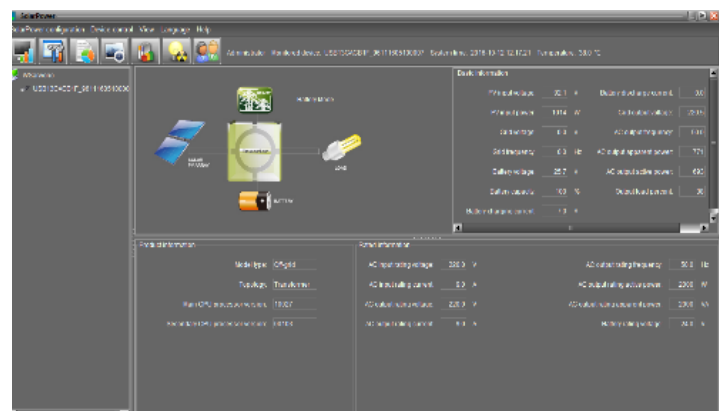

Figure 7. Display of power input and voltage data from solar panel, voltage and battery capacity, charging current of battery, discharging current from battery.

We can save this data in Microsoft Excel for further data processing. The data was recorded every minutes, but for the purposes of data presentation, data is plotted every 10 minutes. The performance test itself was being held for 6 hours, which is from 10 a.m until 4 p.m. The performance test is done at 10 o'clock because the distance is far and the team must buy some measuring instrument first.

The weather condition in Lampung, especially Kalianda, was cloudy with temperature of $27-31^{\circ} \mathrm{C}$ (MSN cuaca). The environmental temperature increases until 13 p.m $\left(31^{\circ} \mathrm{C}\right)$ and then decreases until 16 p.m $\left(27^{\circ} \mathrm{C}\right)$.

The electric voltage and current that produced from solar cell is affected by two physical variables, which are the intensity of solar radiation and environmental temperature [4]. The intensity of solar radiation. received by solar cells is proportional to the voltage and current generated by the solar cells. If the environmental temperature is higher with the fixed-intensity of solar radiation, then the solar panel voltage will decrease and the electric current generated will increase [5].

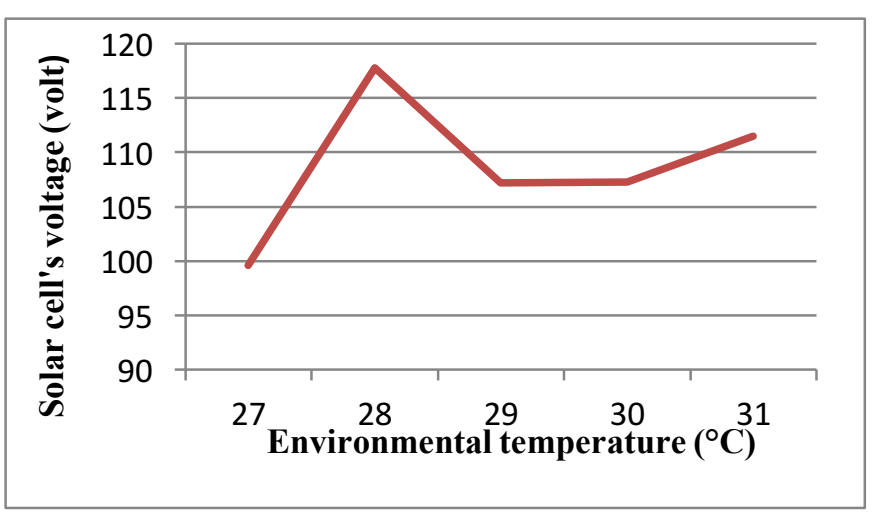

Figure 8. The effect of environmental temperature to solar cell's voltage in South Lampung.

Figure 8 shows that the solar cell's voltage increases significantly when the environmental temperatures increases from $27^{\circ} \mathrm{C}$ to $28^{\circ} \mathrm{C}$, and the highest solar cell's voltage is 117,8 voltage at the environmental temperature of $28^{\circ} \mathrm{C}$

The intensity of solar radiation and the average environmental temperature in South Lampung is shown in Table 1.

Table 1. The intensity of solar radiation and the average environmental temperature in South Lampung on 2016 [6]

\begin{tabular}{ccc}
\hline Month & $\begin{array}{c}\text { The intensity of } \\
\text { solar radiation } \\
\left(\text { Joule } / \mathrm{m}^{2}\right)\end{array}$ & $\begin{array}{c}\text { Temperature } \\
\left({ }^{\circ} \mathrm{C}\right)\end{array}$ \\
\hline May & 120 & 28 \\
June & 152 & 27.2 \\
July & 115 & 26.8 \\
August & 148 & 27.4 \\
September & 171 & 27.4 \\
October & 143 & 27.1 \\
\hline
\end{tabular}

Table 1 shows that the highest intensity of solar radiation during May-October 2016 is on September, which is $171 \mathrm{Joule} / \mathrm{m}^{2}$. Meanwhile the lowest intensity of solar radiation during May-October 2016 is on July, which is $115 \mathrm{Joule} / \mathrm{m}^{2}$.

The environmental temperature also contributes to temperature's changing in solar panel. Due to the temperature rise, the electric power produced by solar panels is reduced [7]. 


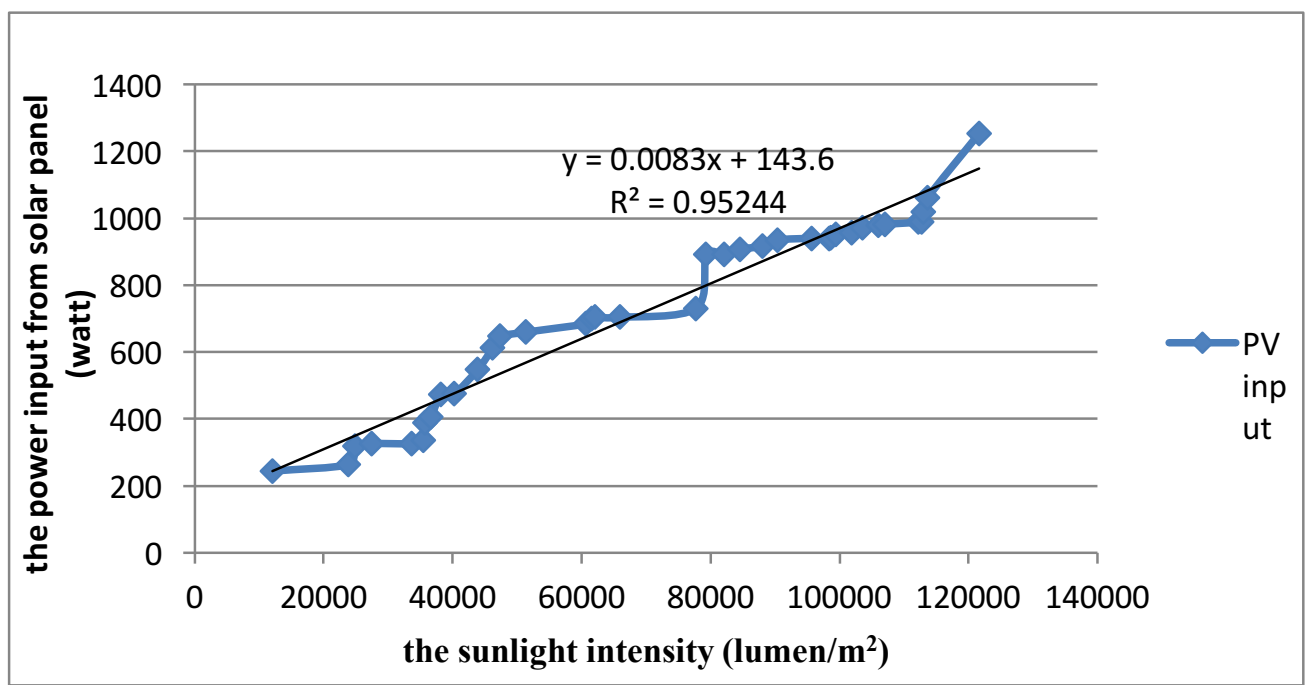

Figure 9. The relationship between the sunlight intensity and the power input from solar panel in South Lampung

From the experimental results, it can be obtained that the minimum sunlight intensity data is 12,010 lumens $/ \mathrm{m}^{2}$, while the maximum solar light intensity is 121,600 lumens $/ \mathrm{m}^{2}$.

According to [3], the earth's atmosphere will reduce the solar radiation through reflection, absorption process (by ozone, water vapor, oxygen, and carbondioxide) and scattering (by air molecules, dust particles, or pollution). For sunny weather during the day, irradiant that reaches the earth's surface is $1,000 \mathrm{~W} / \mathrm{m}^{2}$. Maximum insolation occurs on a clear but partially cloudy day. This is due to the reflection of solar radiation by clouds.

The minimum power input from the solar panel is 245 watts, while the maximum power input from the solar panel is 1253 watts. Minimum battery capacity is $95 \%$ at a voltage of 24.4 volt while the maximum battery capacity is $100 \%$ at 27 volt. Total ice production generated for 6 hours is $28.42 \mathrm{~kg}$ ice or in average per hour generated 4.74 $\mathrm{kg}$.

The relationship between the sunlight intensity and the power input from solar panel in South Lampung is shown in Figure 9.

Figure 9 shows that the relationship between the sunlight intensity and the power input from solar panel in South Lampung is linear with the equation of $y=0,008 x$ $+143,6$. Then the reading of its result is as follows :

1) The power input from solar panel depends on the sunlight intensity.

2) A value of $0.008 x$ is also called a slope that determines the direction of linear regression. The higher the intensity of sunlight then the power input from the solar panel is also higher (the relationship is positive).

3) This slope also estimates the increasing rate in power input from solar panels every day.
+) I valuc Ui itJ.u is aisu valicu all intercept. In this case the intercept means that at the value of $\mathrm{X}=0$, the power input value is 143.6 watt.

5) The determination coefficient $\left(R^{2}\right)$ is 0,952 , so the correlation coefficient $(\mathrm{R})$ is 0.975 . this means the correlation between the intensity of sunlight with the power input from solar panel is 0.975 . The meaning of the correlation value can be seen in Table 2.

Table 2. The explanation of Correlation coefficient's value [8]

\begin{tabular}{|c|c|}
\hline $\begin{array}{c}\text { Correlation coefficient's } \\
\text { value }\end{array}$ & Explanation \\
\hline $0-0.199$ & Very low \\
$0.2-0.399$ & Low \\
$0.4-0.599$ & Enough \\
$0.6-0.799$ & Strong \\
$0.8-1$ & Very strong \\
\hline
\end{tabular}

It means that the correlation between the intensity of sunlight with the power input from solar panel is very strong.

6) Determination coefficient of 95.2 means as much as $95.2 \%$ change in power input from solar panel is affected by the sunlight intensity. While the rest of $4.8 \%(100 \%-952 \%)$ is another factor outside the independent variables.

\section{Conclusion}

1) The highest solar cell's voltage is 117,8 voltage at the environmental temperature of $28^{\circ} \mathrm{C}$.

2) The power input from solar panel depends on the sunlight intensity. The higher the intensity of sunlight then the power input from the solar panel is also higher (the relationship is positive). 
3) The correlation between the intensity of sunlight with the power input from solar panel is very strong.

4) Ninety five point two percent changes in power input from solar panel is affected by the sunlight intensity. While the rest of $4.8 \%$ is another factor outside the independent variables.

5) Solar-powered ice maker produces $4.74 \mathrm{~kg}$ per hour.

in further research, it is better to use solar power meter to measure the intensity of solar radiation.

\section{References}

1 N.A.A. Qasem, and M.A.I. El-Sharawi, Solar Energy, Improving ice productivity and performance for an activated carbon/metanol solar adsorption ice-maker, 98, 523-542 (2013)

2 X.B Bu, H.S Li, and L.B. Wang, Performance analysis and working fluids selection of solar powered rankine-vapor compression ice maker, Solar Energy 95, 271-278 (2013)

3 Muchammad dan E. Yohana, Pengaruh suhu permukaan photovoltaic module 50 watt peak terhadap daya keluaran yang dihasilkan menggunakan reflektor dengan variasi sudut reflektor $0^{\circ}, 50^{\circ}, 60^{\circ}, 70^{\circ}, 80^{\circ}$, Rotasi 12, 14-18 (2010)

4 D. Suryana and M.M, Ali, Pengaruh temperatur/ suhu terhadap tegangan yang dihasilkan panel surya jenis monokristalin (studi kasus : Baristand Industri Surabaya), Jurnal Teknologi Proses dan Inovasi Industri 2, 49-52 (2016)

5 J. Jiang, T. Huang, Y. Hsiao, and C.Chen, Maximum power tracking for photovoltaic power system, Tamkang J. Sci. Eng. 8, 147-153 (2005)

6 Annual report of the Meteorology and Geophysics Agency, South Lampung

7 K. H. Khwee, Pengaruh temperatur terhadap kapasitas daya panel surya, Jurnal ELKHA 5, 23-25 (2013)

8 M. Anggraeni, Kajian Penggunaan Poly Alumunium Chloride (PAC) Dalam Proses Pemurnian Nira Aren dan Lama Pemurnian Terhadap Karateristik Nira Aren (Arenga pinnata Merr), Skripsi Fakultas Teknologi Industri Pertanian, Universitas Padjadjaran (2008) 